\title{
Genetic Diversity of Fig (Ficus carica L.) Based on Morphological Characters and Two-Way Hierarchical Cluster Analysis
}

\author{
Zinab R. Mohamed, Nader R. Abdelsalam ${ }^{1}$ Kamal F. Abdel Latif ${ }^{2}$, Rehab M. Abdelhady ${ }^{3}$
}

\begin{abstract}
There are many local fig accessions cultivated in the world. In Egypt, the accessions are dispersed from Sinai at the east to El-Saloom at the west and from Alexandria at the north to Aswan at the south. Hence, there is no breeding programs were carried out to characterize or improve the Hence, there is no breeding programs were carried out to characterise or improve the Egyptian fig. Twenty-one local cultivated fig (Ficus carrica L.) accessions were collected from different localities from Egypt and Libya country (e.g. 18 accessions from Egypt: Giza, Cairo, Alexandria Marsa-Matrooh governorate and three accessions from Libya. Eight morphological characteristics including leaf traits were used to characterise the fig accessions. Eight morphological traits such as leaf length and width, leaf neck length, leaf lobes, leaf edge, leaf texture, leaf top and color were determinate by the two-way hierarchical cluster analysis of the 21 fig accessions using JMP ${ }^{\circledR} 7.0$ software. In the first way of hierarchical clustering, the fig accessions were distributed into two main groups. The first group includes five clusters separate under two clusters, in the second way of the clusters, the eight leaf morphological traits were distributed into two clusters. Thus, it could be concluded that there are a wide range of variability within the cultivated fig accessions under current study. This diversification could enrich the genetic base of this genus and required more studies to achieve the maximum usefulness from this diversification. Morphological results will be useful in characterizing and to create the first reference and catalogue of the fig accessions.
\end{abstract}

Key words: Fig, morphology, diversity, cluster analysis

\section{INTRODUCTION}

Since the year 1600 until today, it is estimated that many organisms have become extinct in wild environments, a fact that reflects on an accelerated loss of species that exceeds the natural rate of extinction. There are some causes of this loss, but one of the most important factors is habitat destruction mainly caused by human activity. In some cases, human intervention is needed to ensure the survival of species and their populations. The definition of biodiversity includes not only the ecological variability (number of species in a community and their interactions), then also the genetic variability that is critical for natural selection, and thus to the evolution of species. Today, some techniques are available for the detection of genetic diversity, i.e. for identifying DNA polymorphism, including the microsatellite ones. This marker is simply amplified by PCR, requiring no large preliminary totals of DNA samples. Another advantage of its usage compared to other molecular markers is the fact that it has high polymorphism due to a large variation in the number of repetitions. Also, the microsatellite loci have codominant multi-allelic expression which permits the discrimination of homozigous and heterozygous genotypes, facilitating the description of different populations by allele frequency analysis (Bruford et al., 1996).

Consequently, genetic diversity data, based on microsatellites, can be used for monitoring the genetic variability of species and support managing actions to prevent the loss of genetic diversity over time. The genetic diversity obtained from microsatellite data is, in most cases, negatively correlated with the risk of extinction (Evans and Sheldon, 2008). There are several other services of microsatellite markers for conservation purposes. As the intra specific genetic variability is crucial for the persistence of species in wild environments, the diagnosis of genetic variation and how it is geographically distributed are crucial points to characterize its conservation status. Furthermore, a species may be formed by separate units (Moritz, 1994).

Evaluation of genetic variations within cultivated crop species is central to plant breeding strategies and genetic resource conservation (Dean, et al., 1999; Simioniuc, et al., 2002). Losses in the genetic diversity of crop species due to commercialization have led to the need to preserve the present genetic resources as much as possible, not only for the long-term survival of the species but also to ensure enough variability for breeding programs (Esquinas Alcazar, 2005).

Morphological and agronomic characters are useful in surveys of plant species diversity but these characters are highly influenced by environmental conditions. To overcome this, a large array of molecular markers is

\footnotetext{
${ }^{1}$ Agricultural Botany Department Faculty of Agriculture, Saba-Bacha, Alexandria University, ${ }^{2}$ Department of Plant Biotechnology, Genetic Engineering \& Biotechnology Research Institute (GEBRI), University of Sadat City, Sadat City, Minoufiya, Egypt.

3 plant production Department Faculty of Agriculture, Saba-Bacha, Alexandria University

Received April 12, 2017, Accepted May 10, 2017
} 
increasingly used to assess genetic polymorphism. Unfortunately, there has been little research dealing with the genetic diversity in fig germplasm (Aksoy et al., 2003; Stover and Aradhya 2008; Giraldo et al., 2010; Podgornik et al., 2010; Şimşek and Yildirim, 2010; Dalkılıç et al., 2011). To better conserve and utilize genetic resources, characterization designsof morphological variability within the collections and selection of the most significant variables shouldbe carefully performed (Giraldo et al., 2010).

The common fig trees are one of the earliest cultivated fruit-bearing trees $(2 \mathrm{n}=2 \mathrm{x}=26$ chromosomes) belongs to family Moraceae with over 1400 species classified into about 40 genera (Watson, and Dallwitz, 2004). Today, the fig is moderately important world crop, with an estimated annual fruit production of 1,027,194 (FAO, 2011). Fig (Ficus carica L.) is one of the most important fruit species of Mediterranean countries (Polat and Caliskan 2008). In Egypt, where the fig is ubiquitous, many local cultivars have been identified recently. These are designated by farmers mainly based on fruit color and flavor. The local germplasm is therefore subject to problems of homonymy and synonymy. In addition, severe genetic erosion due to biotic and abiotic stresses is threatening this crop. Strategies to preserve the local fig germplasm need to be elaborated. For this purpose and to identity useful genotypes for breeding programs, variation within and between accessions need to be assessed. The main objectives of the present research are to study the morphological characteristic between fig accessions collected from different localities, assessment of genetic differentiation via morphological markers and Two-Way hierarchical cluster analysis.

\section{MATERIALS AND METHODS}

The present experiments were carried out at the Agricultural Botany Department, Faculty of Agriculture, Saba Basha, Alexandria University, Egypt and Plant Molecular Biology Laboratory, Genetic Engineering and Biotechnology Research Institute (GEBRI), University of Sadat city, Minoufiya, Egypt. These studies were conducted during 2014 up to 2016. Twenty-one local cultivated fig accessions were collected from different localities from Egypt and Libya country. The local accessions were collected from different places AbodeyGiza, Adsey-Giza, Aswany, Barry, Bioudi, Black_ Mission, Fayoumi, Green-yellow, Hamouri, Kahramany, Komesrey-EL-Hammam, Koummasri_Cairo, Mejahal, Onok_Alhamama, San _Badr, Sultani black, SultaniGiza, Sultani Red Siwa, Sultani yellow, Sultany Red Amria and White_Fig

\section{Morphological characteristics:}

Eight morphological characteristics including leaf traits were used to characterize the fig accessions. The leaf morphological traits were recorded as following:

1.Leaf length trait was recorded in $\mathrm{cm}$.

2.Leaf width was recorded in $\mathrm{cm}$.

3.Leaf edge shape was recorded as 1: straight, 2: waved, 3: zigzag, 4: serrated.

4.Leaf top shape was recorded as 1: straight, 2: round, 3: brushes.

5.Leaf lobes number was determined as an average of the number of lobes in the leaf.

6.Leaf color was recorded as 1: green yellowish, 2: green, 3: dark green.

7.Leaf texture was recorded as 1: smooth, 2: rough, 3: waxy rough.

8.Leaf neck length: was recorded in $\mathrm{cm}$.

\section{Statistical analysis:}

One Way ANOVA in completely randomized experiments was used to reveal the significant differences among the samples. The LSD (least significant differences) test was conducted to identify the significant differences among the means at 5\% level of probability. Comparison of the mean values is usually calculated after an ANOVA. The latter specify the factors that have significant differences between treatments, while the means comparison display the treatments which are significantly different from the others.

\section{RERSULTS AND DISCUSSION}

\section{Morphological variations of fig accession}

Morphological characteristics have been carried out using eight morphological traits representing the traits characterize the leave of fig trees. The morphological traits including leaf length $(\mathrm{cm})$, leaf width $(\mathrm{cm})$, leaf edge shape, leaf top shape, number of leaf lobes, leaf color, leaf texture and leaf neck length $(\mathrm{cm})$ as shown in Figure 1. The traits were measured during the growing fruit season. The leaves of different accessions were differed in the measured traits which indicate presence of genetic variability in the selected fig accessions.

Analysis of variance of the eight morphological traits of the twenty-one fig local accessions showed highly significant differences among the accessions concerning all the studied morphological traits (Table 1). These results indicate presence of genetic diversity among the fig accessions cultivated in Egypt at the morphological level. The significant variations of the eight morphological traits of the twenty-one fig accessions are presented in Table 1. The smallest leaf length was 
obtained from the accession "Komesrey-El-Hammam" $(5.4 \mathrm{~cm})$ and the least width of the leaf was recorded for "Komesrey-El-Hammam" and "Soultani Yellow" (6 $\mathrm{cm})$. The highest values for the above-mentioned traits were recorded for "Abodey-Giza" leaf length $(23.5 \mathrm{~cm})$ and "Black_Mission" for leaf width $(23 \mathrm{~cm})$ as recorded in Figure 1 and Table 1).

Results in Table 1 recoded the smallest leaf width (cm) for the accessions "Bioudi, Komesrey-ELHammam and Sultani yellow" $(\sim 6 \mathrm{~cm})$ and the highest width of the leaf was recorded for "Black_ Mission" (23 $\mathrm{cm})$. high significant variations were obtained between the different fig accessions as recorded in Figure 1 and Table 1). The twenty-one fig accessions showed different shapes of leaf edge whereas they categorized into 4 groups including strait (1) which includes "Abodey-Giza" and "Kahramany", waved (2) "AdseyGiza", "Aswany", "Bioudi”, "Black_Mission", "Greenyellow", "Sultani black", "Sultani-Giza", "Sultani yellow", "White_Fig", zigzag (3) "Hamouri", "Komesrey-EL-Hammam", "Koummasri_Cairo", "San_Badr" and serrated (4) "Barry", "Fayoumi", "Mejahal", "Onok_Alhamama", "Sultani Red Siwa" and "Sultany Red Amria" (Figure 1 and Table 1).

The leaf top shape trait was categorized into 3 groups including strait (1) which includes "Kahramany", round (2) "Aswany", "Barry", "Bioudi", "Black_Mission", "Fayoumi", "Green-yellow", "Hamouri", "Komesrey-EL-Hammam", "Koummasri_Cairo", "Mejahal", "Sultani- Giza" and "Sultani yellow" and brushes (3) which have one accession "Abodey-Giza", "Adsey-Giza", "Onok_ Alhamama", "San_Badr", "Sultani black", "Sultani Red Siwa", "Sultany Red Amria" and "White_Fig". (Figure 1 and Table 1).

The number of leaf lobes ranged from one lobe for the accessions "Green-yellow", "Sultani Red Siwa" and "Sultany Red Amria", three lobes "Komesrey-ELHammam", "Mejahal" and "San _Badr", four lobes "Bioudi", five lobes "Abodey-Giza", "Onok Alhamama", "Sultani black", "Sultani- Giza", "Sultani yellow" and "White_Fig", six lobes "Hamouri", seven lobes "Adsey-Giza", "Barry", "Fayoumi", "Kahramany", eight lobes "Black_Mission" and "Koummasri_Cairo", ten lobes "Aswany" (Figure 1 and Table 1).

The color of the surface of the leaf was determined as an optical trait by eye as 1 for yellowish green color, 2 for green, 3 for dark green. The leaf color of the fig accessions ranged from yellowish green color for "Aswany", "Sultani- Giza", green for "Abodey-Giza", "Adsey-Giza", "Barry", "Black_ Mission", "Fayoumi", "Green-yellow", "Kahramany", "Komesrey-EL-
Hammam" and "San Badr" and dark green for "Bioudi", "Hamouri", "Mejahal", "Onok Alhamama", "Sultani black", "Sultani Red Siwa", "Sultani yellow", "Sultany Red Amria" and "White_Fig". (Figure 1 and Table 1).

The leaf texture of the fig accessions was recorded as 1 for smooth, 2 for rough and 3 for waxy rough. The leaf texture was rough for most of the accessions such as "Aswany", "Fayoumi”, "Green-yellow", "Komesrey-ELHammam", "Mejahal", "Sultani yellow" and "Sultani black" in which the texture was recorded as rough. The leaf texture in the accessions "Abodey-Giza", "AdseyGiza", "Barry", "Black_ Mission" and "Kahramany" was recorded as waxy smooth and the other accessions were waxy rough (Figure $1 \& 8$ and Table 2). The tallest Leaf neck was recorded for "Kommasri-Cairo" (11.6 $\mathrm{cm})$, whereas the lowest was recorded for the accession "Kommasri-El-Hammam" $(3 \mathrm{~cm})$ as recorded in (Figure 1 and Table 1).

Two-way hierarchical morphological cluster analysis

In the first way of hierarchical clustering, the fig accessions were distributed into two main groups. The first group includes five clusters separate under two clusters. The first cluster included accessions "Sultani Giza", "Kommasri Cairo", the second cluster included "San-Badr" and "Green Yellow", the third cluster contained "Adssey-Giza", and "Aswany", the fourth cluster consisted of "Fayoumi" and "Barry", the fifth cluster included "Aboudey-Giza", "Black-Mission" and "Kahramany" (Figure 2). In the second way of the clusters, the eight leaf morphological traits were distributed into two clusters. The first cluster consisted of the traits "Kommasry-Elhammam", "Bioudi", "Sultany yellow", "Hamouri", "White Fig" and "sultany-Black". On the other hand, the second cluster included the traits includes "Onok-El-Hamama", "Sultani Red Amria", "Mejahal" and "Sultani Red Siwa" (Figure 2).

Thus, it could be concluded that there are a wide range of variability within the cultivated fig accessions under current study. This diversification could enrich the genetic base of this genus and required more studies to achieve the maximum usefulness from this diversification. Morphological results will be useful in characterizing and to create the first reference and catalogue of the fig accessions.

Our results are agreeing with Ben Abdelkrim et al. (2015) used 8 morphological traits and 17 simple sequence repeats loci to characterize 71 cultivated and wild Tunisian fig trees (Ficus carica L.). 
Table 1. Morphological characteristics of fig accessions used in the current experiment

\begin{tabular}{|c|c|c|c|c|c|c|c|c|}
\hline Accessions & $\begin{array}{c}\text { Leaf } \\
\text { length } \\
\text { (cm) }\end{array}$ & $\begin{array}{c}\text { Leaf } \\
\text { width } \\
(\mathrm{cm})\end{array}$ & $\begin{array}{c}\text { Leaf } \\
\text { edge } \\
\text { shape }\end{array}$ & $\begin{array}{c}\text { Leaf top } \\
\text { shape }\end{array}$ & $\begin{array}{c}\text { Leaf lobes } \\
\text { No. }\end{array}$ & Leaf color & $\begin{array}{c}\text { Leaf } \\
\text { texture }\end{array}$ & $\begin{array}{r}\text { Leaf neck } \\
\text { length }(\mathrm{cm})\end{array}$ \\
\hline$\overline{\text { Abodey-Giza }}$ & $23.5 \mathrm{~A}$ & $20.4 \mathrm{D}$ & $1 \mathrm{D}$ & $3 \mathrm{~A}$ & $5 \mathrm{E}$ & $2 \mathrm{~B}$ & $1 \mathrm{C}$ & $11.2 \mathrm{C}$ \\
\hline Adsey-Giza & $14.9 \mathrm{~K}$ & $14.5 \mathrm{~J}$ & $2 \mathrm{C}$ & $3 \mathrm{~A}$ & $7 \mathrm{C}$ & $2 \mathrm{~B}$ & $1 \mathrm{C}$ & $7.4 \mathrm{~J}$ \\
\hline Aswany & $17.1 \mathrm{H}$ & $16.5 \mathrm{I}$ & $2 \mathrm{C}$ & $2 \mathrm{~B}$ & $10 \mathrm{~A}$ & $1 \mathrm{C}$ & $2 \mathrm{~B}$ & $5.8 \mathrm{~N}$ \\
\hline Barry & $18.4 \mathrm{~F}$ & $18.1 \mathrm{H}$ & $4 \mathrm{~A}$ & $2 \mathrm{~B}$ & $7 \mathrm{C}$ & $2 \mathrm{~B}$ & $1 \mathrm{C}$ & $9.8 \mathrm{E}$ \\
\hline Bioudi & $9.5 \mathrm{R}$ & $6.4 \mathrm{~S}$ & $2 \mathrm{C}$ & $2 \mathrm{~B}$ & $4 \mathrm{~F}$ & $3 \mathrm{~A}$ & $3 \mathrm{~A}$ & $6.4 \mathrm{M}$ \\
\hline Black_Mission & $22.2 \mathrm{~B}$ & $23.0 \mathrm{~A}$ & $2 \mathrm{C}$ & $2 \mathrm{~B}$ & $8 \mathrm{~B}$ & $2 \mathrm{~B}$ & $1 \mathrm{C}$ & $10.1 \mathrm{D}$ \\
\hline Fayoumi & $21.6 \mathrm{C}$ & $20.8 \mathrm{C}$ & $4 \mathrm{~A}$ & $2 \mathrm{~B}$ & $7 \mathrm{C}$ & 2B & 2B & $8.9 \mathrm{H}$ \\
\hline Green-yellow & $16.5 \mathrm{I}$ & $14.0 \mathrm{~K}$ & $2 \mathrm{C}$ & $2 \mathrm{~B}$ & $1 \mathrm{H}$ & $2 \mathrm{~B}$ & 2B & $9.5 \mathrm{~F}$ \\
\hline Hamouri & $11.0 \mathrm{Q}$ & $10.8 \mathrm{P}$ & 3B & 2B & $6 \mathrm{D}$ & $3 \mathrm{~A}$ & $3 \mathrm{~A}$ & 5.60 \\
\hline Kahramany & $14.3 \mathrm{M}$ & $20.2 \mathrm{E}$ & 1D & $1 \mathrm{C}$ & $7 \mathrm{C}$ & 2B & $1 \mathrm{C}$ & 10.1D \\
\hline Komesrey-EL-Hammam & $5.4 \mathrm{~S}$ & $6.0 \mathrm{~T}$ & 3B & 2B & $3 \mathrm{G}$ & 2B & 2B & $3 \mathrm{Q}$ \\
\hline Koummasri_Cairo & $20.0 \mathrm{E}$ & $21.2 \mathrm{~B}$ & 3B & 2B & $8 \mathrm{~B}$ & $1 \mathrm{C}$ & $3 \mathrm{~A}$ & $11.6 \mathrm{~A}$ \\
\hline Mejahal & $14.5 \mathrm{~L}$ & $12.0 \mathrm{~N}$ & $4 \mathrm{~A}$ & 2B & $3 \mathrm{G}$ & $3 \mathrm{~A}$ & 2B & $6.8 \mathrm{~L}$ \\
\hline Onok_Alhamama & $12.4 \mathrm{O}$ & $12.5 \mathrm{M}$ & $4 \mathrm{~A}$ & $3 \mathrm{~A}$ & $5 \mathrm{E}$ & $3 \mathrm{~A}$ & $3 \mathrm{~A}$ & $8.4 \mathrm{I}$ \\
\hline San_Badr & $18.2 \mathrm{G}$ & $18.5 \mathrm{G}$ & 3B & $3 \mathrm{~A}$ & $3 \mathrm{G}$ & 2B & 2B & $11.5 \mathrm{~B}$ \\
\hline Sultani black & $13.5 \mathrm{~N}$ & $6.8 \mathrm{R}$ & $2 \mathrm{C}$ & $3 \mathrm{~A}$ & $5 \mathrm{E}$ & $3 \mathrm{~A}$ & 2B & $6.8 \mathrm{~L}$ \\
\hline Sultani- Giza & 20.4D & $19.5 \mathrm{~F}$ & $2 \mathrm{C}$ & 2B & $5 \mathrm{E}$ & $1 \mathrm{C}$ & $3 \mathrm{~A}$ & $9.5 \mathrm{~F}$ \\
\hline Sultani Red Siwa & $14.5 \mathrm{~L}$ & $11.0 \mathrm{O}$ & $4 \mathrm{~A}$ & $3 \mathrm{~A}$ & $1 \mathrm{H}$ & $3 \mathrm{~A}$ & 2B & $4.8 \mathrm{P}$ \\
\hline Sultani yellow & $9.5 \mathrm{R}$ & $6 \mathrm{~T}$ & $2 \mathrm{C}$ & 2B & $5 \mathrm{E}$ & $3 \mathrm{~A}$ & 2B & $6.4 \mathrm{M}$ \\
\hline Sultany Red Amria & $15.5 \mathrm{~J}$ & $13 \mathrm{~L}$ & $4 \mathrm{~A}$ & $3 \mathrm{~A}$ & $1 \mathrm{H}$ & $3 \mathrm{~A}$ & $3 \mathrm{~A}$ & $9.4 \mathrm{G}$ \\
\hline White_Fig & $11.4 \mathrm{P}$ & $8.6 \mathrm{Q}$ & $2 \mathrm{C}$ & $3 \mathrm{~A}$ & $5 \mathrm{E}$ & $3 \mathrm{~A}$ & $3 \mathrm{~A}$ & $7.2 \mathrm{~K}$ \\
\hline Mix & 23.5 & 23 & 4 & 3 & 10 & 3 & 3 & 11.6 \\
\hline Min & 5.4 & 6 & 1 & 1 & 1 & 1 & 1 & 3 \\
\hline Average & 15.44 & 14.25 & 2.66 & 2.33 & 5.04 & 2.28 & 2.09 & 8.10 \\
\hline S.D & 5.12 & 5.80 & 1.04 & 0.62 & 2.65 & 0.73 & 0.77 & 2.53 \\
\hline S.S. & $876^{* *}$ & $1248^{* *}$ & $41.3^{* *}$ & $13.3 * *$ & $242 * *$ & $20.6^{* *}$ & $23.6^{* *}$ & $219^{* *}$ \\
\hline
\end{tabular}

* Levels not connected by same letter are significantly different.

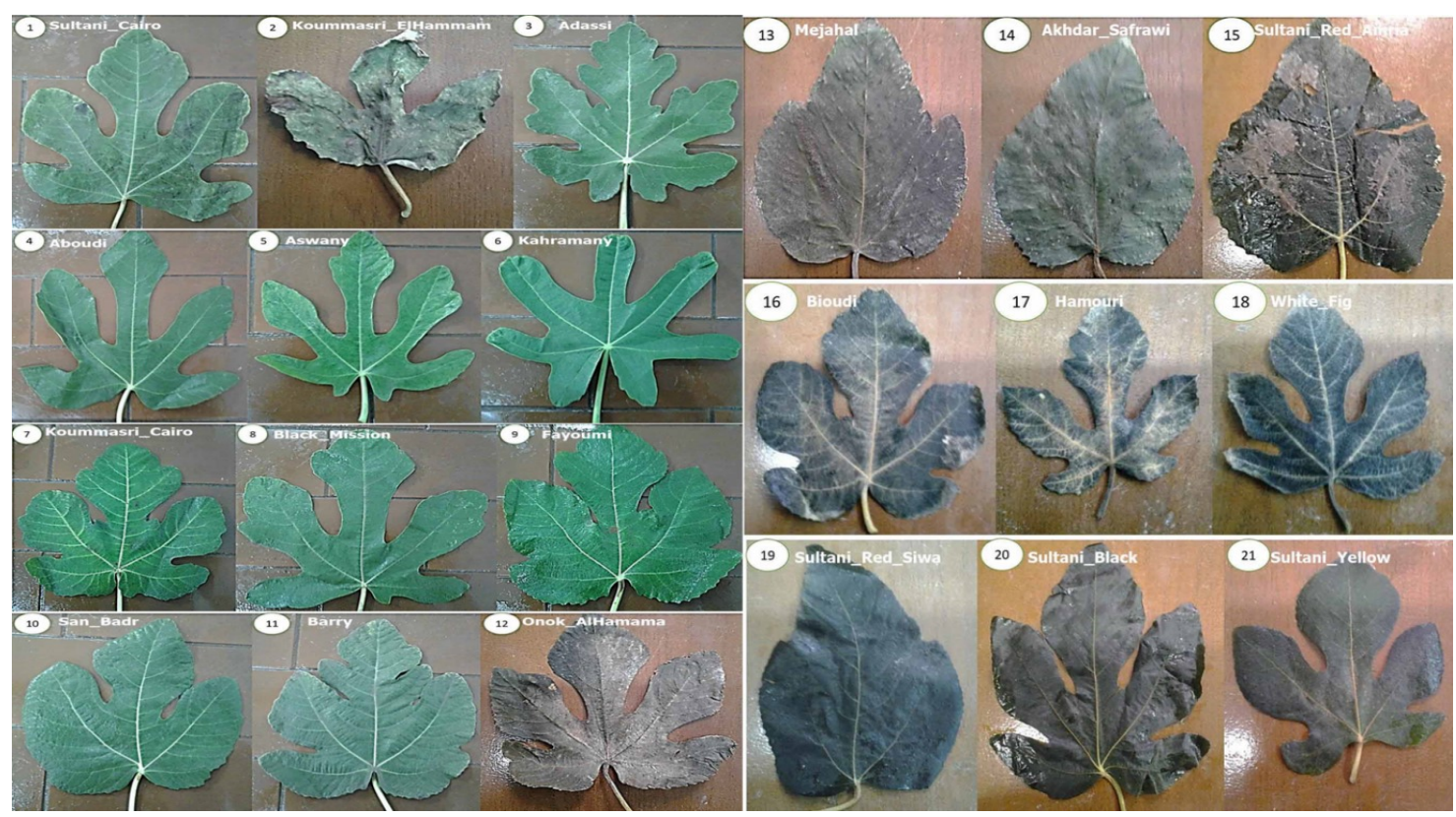

Figure 1. Morphological variations of fig accessions used in the current experiment 
- Galtani- Gza

- Kourmesiri Caro

- San_Badr

- Greeryellow

- Adsey-Giza

- ASwany

- Fayoumi

"Barry

- Abodev-Gza

- Back_Mssion

- Kahramery

- Komesrey-B-Harman

"Eoudi

- Gltani yellow

- Hamouri

- White_Fig

- Gultani black

- Onok_Alharrarra

- Gltary Red Amria

- Michal

- Gultani Red Giwa
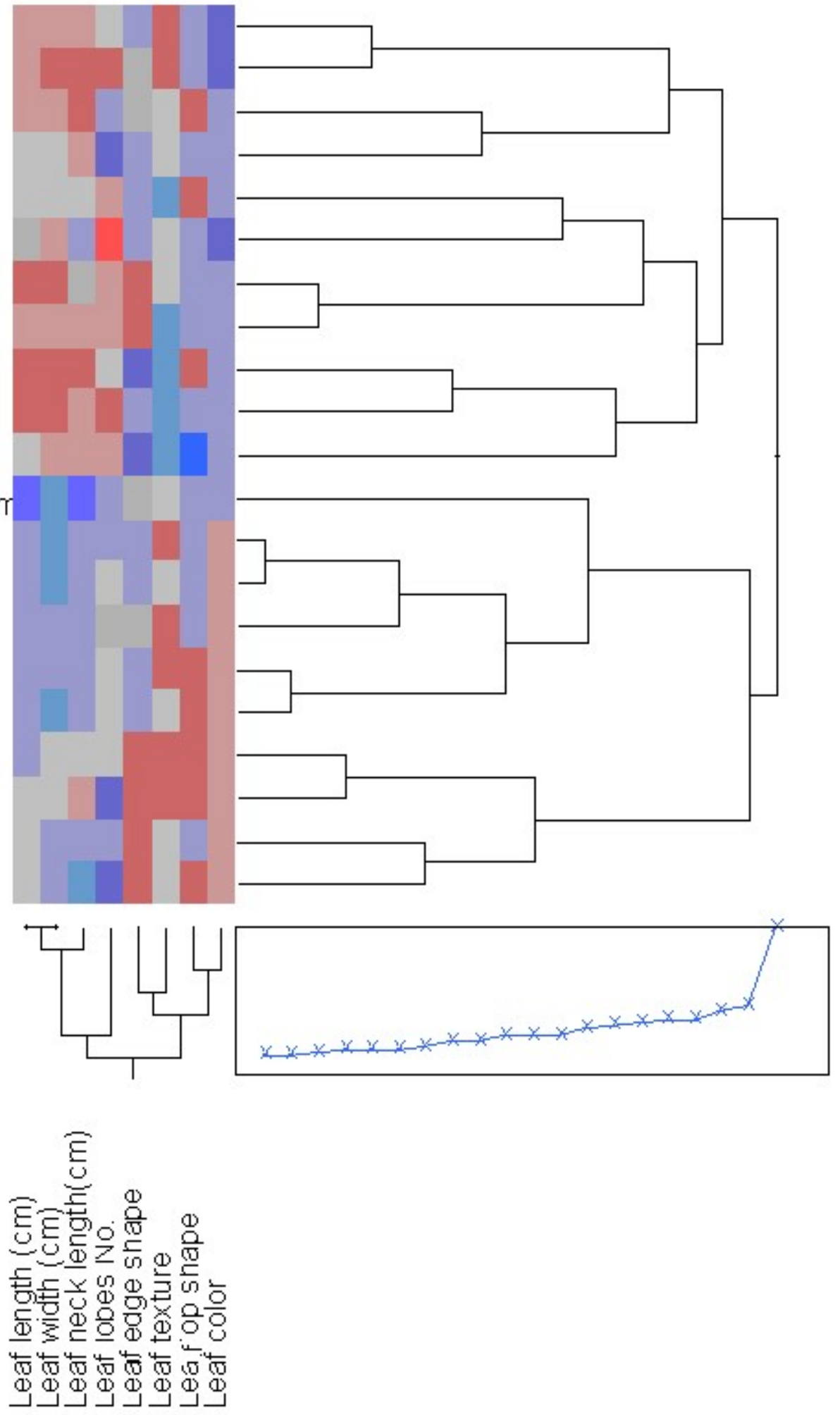

Figure 2. Two-Way hierarchical cluster analysis of twenty-one local fig accessions and eight morphological traits 
Their results showed that significant morphological differences were inferred from leaf traits. The statistical analysis showed two major fig groups that indicated a common morphological basis. Moritz, (1994) reported that for a sustainable increase in fig production, there is a need to develop new table figs while considering the maturity period, quality, and preferences of the consumer. The table figs found in Turkey, mostly local cultivars or accessions, are grown in the Mediterranean, Marmara, Black Sea, and southeastern regions. There are numerous local cultivars with a variety of sizes, shapes, ripening times, skin and pulp colors, and taste. Both morphological characterization and the protection of this genetic diversity for future generations are very important. In this study, plant and fruit characteristics of the local fig accessions were identified. Figs ripen once or twice per year, depending on the accession. Our results in line with Stover et al. (2007). Who determined 2 accessions (Bardak and Dolap) to be first crops and the other 74 accessions were main crops. The first crops matured after 15 June, which is late for breba. The full maturation of the main crops was found to be very promising because the extension of the marketing period, as very early (Erkenci), early (19 accessions), and late (6 accessions). About the fruit widths given in the fig descriptor list, $27.6 \%$ of the samples were large $(50-60 \mathrm{~mm})$ or very large $(>60 \mathrm{~mm})$. Fruit skin color of fresh figs is especially important for consumer preferences, and fruit skin and flesh color are used to determine ripening time. These characteristics are also used together with other features in determining the selection of accessions used in breeding studies. Fresh figs with pink and red flesh color are preferred by consumers. In this study, fig accessions commonly had the pink and red flesh colors desired. When our results were compared to previous studies performed in diverse ecological conditions in Turkey, differences were detected for some of the pomological traits.

These differences might be due to the genotypic diversity or environmental effects on fruit characters. The PC analysis indicated that there were great variations among accessions in terms of plant and fruit traits. Accessions with similar parameters sampled from different locations were clustered in the same groups. We can say that such clustering was observed due to the high number of selected accessions, as well as the presence of synonym, homonym, and similar accessions in the eastern Mediterranean region of Turkey.

It is possible that the same name was given to several genetically different fig cultivars with similar morphological characteristics in this region. Only 11 out of 26 plant traits could successfully distinguish different accessions. The number and shape of lobes (Saddoud et al. 2008), tree growth habit, size of the tree, degree of branching, number of lobes per leaf (Giraldo et al. 2010), leaf length, leaf width, leaf area, density of hairs/spicules on the leaf 's upper surface, and petiole thickness (Podgornik et al. 2010) were the traits used for the discrimination of fig accessions.

In addition, it can be very useful to use $\mathrm{AD}, \mathrm{LS}, \mathrm{FN}$, and $\mathrm{LN}$ for the identification of fig germplasm. In the fig accessions, 26 of 38 fruit characters could explain $47.3 \%$ of the total variation. The most important discriminators of fig fruits were the fruit weight, fruit length, fruit diameter, fruit skin and flesh color (Saddoud et al. 2008; Podgornik et al. 2010), fruit shape (Giraldoet al. 2010; Podgornik et al. 2010), firmness of the fruit skin (Saddoud et al. 2008; Podgornik et al. 2010), fruit skin cracks (Saddoud et al. 2008), production type, skin firmness (Giraldo et al. 2010), fruit neck length (Podgornik et al. 2010), abscission of the stalk from the twig (Podgornik et al. 2010), stalk diameter, neck diameter, ostiole diameter, ostiole opening, and flesh thickness.

\section{REFERENCES}

Aksoy U, Can HZ, Misirli A, Kara S, Seferoglu G, Sahin N 2003 Fig (Ficus caricaL.) selection study for fresh market in Western Turkey.ActaHort 605: 197-203.

Ben Abdelkrim Ahmed, Baraket Ghada, Essalouh Laila, Achtak Hafid, Khadari Bouchaib, Salhi-Hannachi Amel 2015 use of morphological traits and microsatellite markers to characterize the Tunisian cultivated and wild figs (Ficus carica L.). Biochemical Systematics and Ecology 592015 209e219

Bruford, M.W., Cheesman, D.J., Coote, T., Green, H.A.A., Haines, S.A., O'Ryan, C. and Williams, T.R. 1996 Microsatellite and Their Application to Conservation Genetics. In: Smith, T.B. and Wayne, R.K, Eds., Molecular Genetic Approaches in Conservation, Oxford University Press, New York, 278-297.

Dalkılıç Z, Mesav HO, Günver-Dalkılıç G, Kocataş H 2011 Genetic diversity of male fig (Ficus carica caprificusL.) genotypes with random amplified polymorphic DNA (RAPD) markers. Afr J Biotechnol 10:519-526

Dean, R.E., J.A. Dahlberg, M.S. Hopkins, 15. Cabrita, L.F., U. Aksoy, S. Hepaksoy and J.M. Leitao,C.V. Mitchell and S. Kresovich, 1999. Genetic redundancy and diversity among 'orange' accessionsin the US national sorghum collection assessed withsimple sequence repeat (SSR) markers. Crop Science,39: 1215-1221.

Esquinas Alcazar J 2005 Protecting crop genetic diversity for food security: political, ethical and technical challenges. Nat Rev Genet 6: 946-953. 
Evans. S.R. and Sheldon, B.C. 2008 Interespecific Patterns of Genetic Diversity in Birds: Correlations with Extinction risk. Conservation Biology, 22, 1016-1025. http://dx.doi.org/10.1111/j.1523-1739.2008.00972.x

F.A.O. Stat Agricultural Data. 2011 .http://faostat.ao.org/.

Giraldo E, Lopez Corrales M, Hormaza JI 2010 Selection of the most discriminating morphological qualitative variables for characterization of fig germplasm. J AmerSocHort Science 135: 240-249

Moritz, C. 1994 Defining Evolutionary Significant Units for Conservation. Trends in Ecology and Evolution, 9, 373375. http://dx.doi.org/10.1016/0169-5347(94)90057-4

Podgornik M, Vuk I, Vrhovnik I, Mavsar DB 2010 A survey and morphological evaluation of fi g (FicuscaricaL.) genetic resources from Slovenia.SciHort 125: 380-389.

Polat AA. And Çalişkan O. 2008 Fruit characteristics of fi g cultivars and genotypes grown in Turkey. SciHort 115: 360-367.
Saddoud, O., K. Chatti, A. Salhi-Hannachi, M. Mars, A. Rhouma, M. Marrakchi and M. Trifi 2008. Genetic diversity of Tunisian figs (FicuscaricaL.) as revealed by nuclear microsatellites.Hereditas, 144: 149-157

Simioniuc, D., R. Uptmoor, W. Friedt and F. Ordon, 2002. Genetic diversity and relationships among peacultivars (PisumsativumL.) revealed by RAPDs andAFLPs. Plant Breeding, 121: 429-435.

Şimşek M, Yildirim H 2010 Fruit characteristics of the selected fi g genotypes.Afr J Biotechnol 9: 6056-6060.

Stover E, Aradhya M 2008 Fig genetic resources and research at the US National Clonal Germplasm Repository in Davis, California.ActaHort 798: 57-68.

Watson, L. and M.J. Dallwitz 2004. The families offlowering plants: descriptions, illustrations,identification and information retrieval. Available inhttp://delta-intkey.com [20 May, 2010].

\section{الملخص العربي}

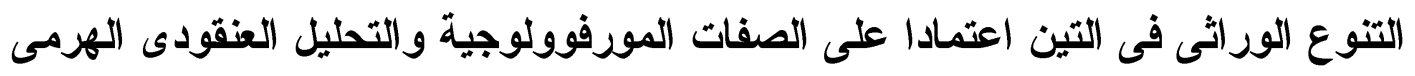

$$
\text { زينب رمضان، نادر عبد السلام، كمال عبد اللطيف، ريحاب عبد الهادى }
$$

مورفولوجيا اعتمادا على الاختلافات فى شكل الاوراق ونم

اجراء التحليل الاحصائى لعدد ثمانية صفات مورفولوجية

مختلفة ومن ثم تم ادخال البيانات المورفولوجية الى برنامج

التحليل العنقودى الهرمى لدراسة البعد الوراثة بين تلك ماتك

الاصناف المنتشرة اعتمادا على خضائصها المورفولوجية

وتمهيدا لبدء برنامج تربية مستقبلية. واوضحت النتائج ان

هناك مجموعتين اساسيتين للتين المنزرع فى مصر يمكن

$$
\text { الاستلال بها فى بر امج التربية. }
$$

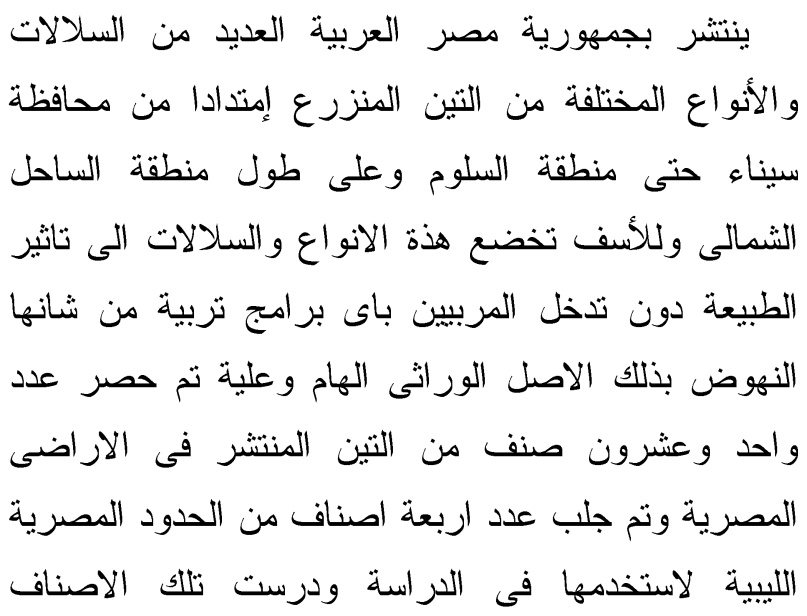

